\title{
MACROECONOMIC FACTORS INFLUENCING THE DEVELOPMENT OF UKRAINE'S FOREIGN TRADE
}

\author{
Svitlana Tkalenko', Tetyana Melnyk ${ }^{2}$, Liudmyla Kudyrko³
}

\begin{abstract}
The purpose of the study is to assess the relationship between Ukraine's foreign trade and its major macroeconomic indicators in the context of deepening globalization processes and increasing dependence of national economic development on exogenous determinants. In order to achieve this goal, the most important factors of influence of macro level on the scale of foreign trade turnover have been selected, the interval of observations has covered 1999-2018. Authors used the method of economic and mathematical modeling based on the E-Views software. A multifactor regression model has been constructed, tested for autocorrelation and heteroskedasticity; causal effects have been identified between foreign trade and the main macroeconomic indicators of combinatorial nature (both exogenous and endogenous), Ukraine's foreign trade volumes has been forecasted up to 2023. Methodology. The study is based on the analyzed macroeconomic indicators for the period of 1999-2018, which made it possible to select those that showed up greatest impact on foreign trade. The results of the conducted modeling showed: high level achievement of foreign trade dynamics of Ukraine over the mentioned years, which exceeded similar indicators of dynamics of global trade; strong link between foreign trade, foreign direct investment and employment; revealing of a significant influence upon foreign trade of innovative activity of national business in industry as a dominant segment of the foreign sector of the country. As conclusions, the authors formulated a thesis on the need to strengthen institutional support for innovation and investment activities of national enterprises as a driver for scale-up and improvement of quality of Ukraine's trade relations with the entire world. It is determined that the multiplicative interaction of innovation and investment would diversify and complicate the commodity structure of exports, increase the level of its technological and innovative nature, and thus it is to allow to get rid of the established attitude to Ukraine on the trading map of the world as a supplier of low-tech raw materials. Practical implications. The main theoretical propositions, the authors' conclusions presented in the article, are supposed to form a methodological basis for expert evaluation in substantiating the priorities of the state policy modernization regarding conditions and factors promoting the export-oriented sectors of the national economy. Value/originality. Prospects for further research in this sphere may be to assumed onto making an assess on risks (threats) and macroeconomic effects of foreign trade deterioration in the context of declining economic activity regarding importing countries of their domestic products, especially in the EU and the PRC, further weakening of external channels of investment and reducing the ability of businesses to innovate in deepening recessionary processes on the global and national levels.
\end{abstract}

Key words: effect of foreign trade, foreign direct investment, innovation, export-import, trade policy, economic growth.

JEL Classifications: F12, F17, F42, F43

\footnotetext{
Corresponding author:

${ }^{1}$ Kyiv National Economic University named after Vadym Hetman, Ukraine.

E-mail: sv.tkalenko@gmail.com

ORCID: https://orcid.org/0000-0003-0385-846X

ResearcherID: https://publons.com/researcher/1924024/svitlana-tkalenko/

${ }^{2}$ Kyiv National University of Trade and Economics, Ukraine.

E-mail: t.melnyk@knute.edu.ua

ORCID: http://orcid.org/0000-0002-3839-6018

ResearcherID: https://publons.com/researcher/1673478/tetiana-melnyk/

${ }^{3}$ Kyiv National University of Trade and Economics, Ukraine.

E-mail: 1.kudyrko@knute.edu.ua

ORCID: http://orcid.org/0000-0002-9089-7223

ResearcherID: https://publons.com/researcher/1688352/liudmyla-kudyrko/
} 


\section{Introduction}

The link between foreign trade and economic growth has been and still remains the subject of intense scientific debate, and the effects of foreign trade, both in the scientific and expert environment, are recognized as ambiguous and unpredictable. Thus, for a long time, some theoretical assumptions about the impact of international trade on the well-being and economic growth of countries have been unquestionably confirmed in the numerous empirical studies of some particular researchers and international institutions. Currently, the experts' conclusions of international organizations are more prudent and cautious. According to the figurative statement of experts from the IMF and the World Bank, "studying the relationship between global trade and income is like analyzing the behavior of a drunk and his puppy dog: neither is walking in a straight line, but we nevertheless expect them to remain fairly close to each other" (Constantinescu, Cristina, Aaditya Mattoo, and Michele Ruta, 2014).

The novelty of the study presented in this article is to substantiate and econometrically testify functional links between foreign sector of the country in terms of its trade component and important indicators of the development of national economy of the open type, reflecting endogenous and exogenous determinants (labor, capital, innovations). Such an approach will allow to gain more objective understanding of the interdependencies between the external and internal factors of development of the Ukrainian economy and, also, it is to build a fundamental methodological basis for expert evaluation in substantiating the priorities of state policy modernization regarding the conditions and factors contributing to the export-oriented sectors of national economy in conditions of global challenges of the $21^{\text {st }}$ century.

The issues raised in the article are of extremely acute touch regarding realities of modern Ukraine. Thus, during the years of observation chosen by the authors of the time interval, the dynamism of Ukraine's foreign trade obviously exceeded similar indicators in the world: if the growth rate of global trade in 2018 compared to 2000 was about $310 \%$ (UNCTAD), this indicator was more impressive in Ukraine and it reached almost 345\% (UNCTAD). While global trade and production slowed down by a positive percentage in the aftermath of the 2007-2008 global crisis, Ukraine's shrinking demand in foreign markets was just reflected as for the catastrophic European 15\% of GDP (UNCTAD) decline. Subsequently, since 2014, Ukraine has lost one third of its export potential caused by the Russian aggression. Within the time period the article was being written, the world and the national economy were on the verge of the next economic crisis, requiring new understanding for determinants of economic development, and in the context of clear reduction of both external and internal sources of financing, the selection of those channels of foreign trade stimulation that proved to be the most sensitive and effective.

The issues raised are not limited to the national economy, effects and interdependence between foreign trade and individual macroeconomic indicators have an ambiguous and mixed effect onto some other economies of the world. Despite the fact that econometric testing and development of a model on the Ukrainian statistics has become a direct research task for the authors, it should also serve to analyze external sector of other countries involved into the global trade.

\section{Scientific literature review}

Effects and interconnections of foreign trade have very often been exemplified in the scientific literature by one single country or region. Although, there is no particular theory that clearly links effects of trade with economic growth, evidence of trade's positive effects on economic growth is available in some countries.

Thus, studies concerning the effect of foreign trade, taking developed countries samples into account, prove the statement that the correlation between foreign trade and economic growth may be both negative or positive. It depends on the stage (period) of economic development of the country and interaction of a number of other factors in the context of globalization (SookYen, Lee and Chin Mui-Yin, 2018). In particular, the United States scientists consider such an aspect of the problem as the consequences and impact of trade openness onto changeable trading conditions, the inflow of investment, their cyclicality from the point of view on economies spreading out (Razin, Sadka, \& Coury, 2003). In this study, to evaluate the exact link between economic growth and trade, including its openness, the vectoral auto-regressive (VAR) model method is used. Some other researchers note that the Internal Market Openness Index is a key element of the globalization process, since tariff and quota withdrawal increases international trade; so, China, which manipulates the latent regulators of foreign trade, is determined to be the biggest trading fraud (Ceyhun Akarsu, 2018).

In the focus of the authors' attention, studies on the impact of trade openness on economic growth in transition economies were fully justified. In particular, studies have been conducted in a number of countries, including Balkan countries, such as Albania, Bosnia and Herzegovina, Croatia, Bulgaria, Macedonia, Romania, Slovenia, Montenegro, Greece and Serbia, have confirmed the positive effect of foreign trade (Eglantina, Oltiana, 2016; Engjëll Pere \& Eniel Ninka, 2017). At the same time, these kinds of outlined approaches adaptive to some scientific researches bearing in mind specifics of Ukraine do not give the opportunity to focus on the formation of risks of large-scale imports, which causes an increase in external public debt, increase in inflation 
and, as a consequence - insufficient (lack of) attraction of foreign investment, including export-oriented industries.

In our opinion, the conclusions of the national researcher are of fundamental importance that in terms of integration of Ukraine into the system of international trade relations, where, along with the increase in size of a trading partner, the volumes of small economies trade, which is being the economy of Ukraine, are more sensitive to the magnitude of income from export (Chugayev, 2016). Indeed, it is a matter of fact that having priority partners of the powerful counterparties (the EU and the PRC), the Ukrainian economy through additional trade channel with them entails additional risks. However, the country size factor cannot be considered as an autonomous and dominant one when explaining the effects of trade. In this sense, the approach proposed by the authors to account for a complex of factors of influence is more prudent.

The study of the effect of foreign trade in developing countries, showing factors that have both positive and negative effects on trade, cannot be overlooked. In particular, public debt and the exchange rate have either negative effect on trade, and liberalization measures in developing countries have become determinants of the positive effect of foreign trade (Nwosa P., Saibu M., Fakunle O., 2012; Ejike, D., Arinze A. S. \& Chidi O. F., 2018; Agbeyegbe T., Stotsk, J. G. \& Wolde Mariam A. 2004). Scholars say that in these countries, the main challenges are institutional and structural changes that have been aimed at promoting trade and export activity. Considering importance of these investigations, we believe that this approach focuses more on the trade-related effects of the regulatory component (public finances, monetary policy, foreign trade regulation), but does not provide answers and explanations for fundamental factors from the sphere of real sector.

The newly introduced emphasis of foreign trade effect as for measuring the variability of trade policy and production as well as marketing cooperation with other countries is presented in the worked-out issues on the impact of international competition upon the efficiency of national production and consumption conditions (Alessia Campolmi, Harald Fadinger, Chiara Forlati, 2014). At the same time, the authors of this article are convinced that this approach needs clarification, since the competitiveness of the state's foreign sector business integrated into the system of international cooperative relations is conditioned not only by trade regulations (Yanikkaya, 2003), but should cover over its issues on innovation strength and investment attractiveness.

In our opinion, the study on the effects of regional trade agreements drafting is meaningful and profound (World Bank Policy Research Working Paper, 2007). Such studies point out onto the ambiguous effects of trade agreements, especially for developing countries.
However, it should be noted that appealing to regional aspects of foreign trade only, a certain investigational entrapment is turning out: this is the different effectiveness as for trade agreements consequences influencing economies of the same member-countries, being a part of various integration unions, that are located on the same continent.

Our attention has also been drawn to developments, in which the effect of foreign trade is viewed through the formation of export-oriented strategies both on the state level and also for some particular companies. The authors argue in favor of this thesis. Firstly, the increase in production and trade is going to lead to productivity gains on through increased economies of within the export sector volume, and positive external effects. Secondly, exports contribute to more efficient allocation of resources through the specialization and manufacture of the most competitive merchandise. Thirdly, enhancing the effectiveness of foreign trade also contributes to more efficient managerial process and increases overall economic productivity (Mahadevan, 2007). These studies typically reveal the relationship between exports and economic growth (Marilyne Huchet, Chantal Le Mouel, Mariana Vijil, 2018). However, the issue of the import component and its role in economic growth remains sometimes beyond attention.

\section{Methodology}

The study is based on the analyzed macroeconomic indicators, in particular, GDP (measuring scales of economic activity domestically), LM (the number of employed population, which reflects endogenous personnel resource of the national economy (labor)); SI (expenses for innovation of legal entities and their units engaged into industrial activities (internal resource, innovation)); FDI (foreign direct investment involved into the Ukrainian economy (external resource, capital)).

The authors constructed a multifactorial regression model, namely: the hypothesis of significant impact of macroeconomic factors of endogenous and exogenous origin onto foreign trade have been tested (FT) as for national economy using the E-Views software. The use of E-Views by authors is due to the fact that it is currently one of the most powerful packages for the construction of econometric models. By virtue of this, there would be possible to solve a number of important research problems like the analysis of scientific information; macroeconomic forecasting; modeling of economic processes; forecasting market conditions and many more. Therefore, selecting a software product is relevant in terms of instrumental capabilities to the tasks positioned by the authors. The general appearance of the FT model illustrating the relationship of the selected variables can be described by the following equation: 
$\mathrm{FT}=\mathrm{f}(\mathrm{GDP}, \mathrm{FDI}, \mathrm{LM}, \mathrm{SI})$,

where, FT - foreign trade of goods and services of Ukraine, mln. USD (export, import); GDP - Ukraine's GDP, mln. USD; FDI - Foreign Direct Investment in Ukraine, mln. USD; LM - employed population, mln. of people; SI - Innovation Costs, mln. USD.

A correlation matrix was constructed to analyze the model, which explains the relationship between the variables. The results of multivariate regression estimation have been analyzed. The model is adequate if the rules of the functioning process of the real economic system have been reflected. The constructed model was tested for autocorrelation and heteroskedasticity, which was tested on for verifying classical assumptions and for checking predictive quality of the regression model. The investigated results of these tests proved the adequacy of the model. The cause and effect relationships between the selected variables and the FT were investigated using the Granger test. The high quality of the model was proved, and, therefore, foreign trade forecast up to 2023 was made on that basis.

\section{Research results}

The role and place of any country on the world economy in general, and world trade as its component in particular, depends on many factors, the main of which the authors consider to be the dynamics of development of the national economy, the degree of its openness and involvement into international division of labor, its ability to adapt to the turbulent conditions of international economic life. An important indicator of the intensity of inter-country economic ties is the share of their mutual trade within the volume of trade with all countries of the world, because this indicator reflects general level of technical and economic development of partner countries, the extent of investment exchange, the state of industrial cooperation of enterprises, as well as other directions for integration of their economies indeed. The main indicators of the Ukrainian economy in terms of international economic relations are given below (table 1).

The authors conducted statistical and empirical analysis of the development of the economy of Ukraine over the period that allowed to reveal certain regularities. Firstly, foreign trade tends to grow steadily in both absolute and relative terms, including such periods as the global economic crisis (2008) and the period of Russian aggression in eastern Ukraine (2014-2018). Ukraine's situation, namely the loss of one third of its export potential due to events in the East, has negative impact on economic development and its economic security: in the first year after the loss of territories (2015), the loss of foreign trade has been $28.1 \%$, outflow of foreign capital calculated minus $24.2 \%$, and almost $30 \%$ drop in GDP.

Ukraine's foreign trade operations have been conducted within 173 countries (as of 2019). Traditionally, the main partner-countries in export are the countries of the European Union, namely Poland,

Table 1

Some indicators of the intensity of the Ukrainian economy

\begin{tabular}{|c|c|c|c|c|c|c|c|}
\hline Year & $\begin{array}{c}\text { Export of goods, } \\
\text { mln. USD }\end{array}$ & $\begin{array}{c}\text { Import of goods, } \\
\text { mln. USD }\end{array}$ & $\begin{array}{c}\text { Export } \\
\text { of service, } \\
\text { mln. USD }\end{array}$ & $\begin{array}{c}\text { Import } \\
\text { of services, } \\
\text { mln. USD }\end{array}$ & $\begin{array}{c}\text { Growth rate } \\
\text { of foreign trade, } \\
\%\end{array}$ & $\begin{array}{c}\text { FDI, } \\
\text { mln. USD }\end{array}$ & $\begin{array}{c}\text { Growth rate } \\
\text { of FDI, } \\
\%\end{array}$ \\
\hline 1999 & 11581.6 & 11846.1 & 3613.9 & 1113.2 & - & 2810.7 & - \\
\hline 2000 & 14572.5 & 13956 & 3655.1 & 1151 & 18.4 & 3281.8 & 16.8 \\
\hline 2001 & 16264.7 & 15775.1 & 3731.9 & 1147.6 & 10.8 & 3875 & 18.1 \\
\hline 2002 & 17957.1 & 16976.8 & 4303.8 & 1194.9 & 9.5 & 4555.3 & 17.6 \\
\hline 2003 & 23066.8 & 23020.1 & 4524.9 & 1465.3 & 28.8 & 5471.8 & 20.1 \\
\hline 2004 & 32666.1 & 28996.8 & 5612.7 & 2062.9 & 33.1 & 6794.4 & 24.2 \\
\hline 2005 & 34228.4 & 36136.3 & 6443.2 & 2941.8 & 15.0 & 9047 & 33.2 \\
\hline 2006 & 38368 & 45038.6 & 7791.8 & 3730.6 & 19.0 & 16890 & 86.7 \\
\hline 2007 & 49296.1 & 60618 & 9435.1 & 4995.5 & 31.0 & 21607.3 & 27.9 \\
\hline 2008 & 66967.3 & 85535.3 & 12260.1 & 6481.5 & 37.7 & 29542.7 & 36.7 \\
\hline 2009 & 39695.7 & 45433.1 & 10129.7 & 5186.4 & -41.3 & 35723.4 & 20.9 \\
\hline 2010 & 51405.2 & 60742.2 & 12324.2 & 5467.2 & 29.4 & 38992.9 & 9.2 \\
\hline 2011 & 68394.2 & 82608.2 & 11936.3 & 5421.6 & 29.6 & 45370 & 16.4 \\
\hline 2012 & 68830.4 & 84717.6 & 14180.3 & 6214.2 & 3.3 & 48197.6 & 6.2 \\
\hline 2013 & 63320.7 & 76986.8 & 14096.2 & 6650.1 & -7.4 & 51705.3 & 7.3 \\
\hline 2014 & 53901.7 & 54428.7 & 14233.2 & 7523 & -19.2 & 53704 & 3.9 \\
\hline 2015 & 38127.1 & 37516.4 & 11520.8 & 6373.1 & -28.1 & 40725.4 & -24.2 \\
\hline 2016 & 36361.7 & 39249.8 & 9736.6 & 5523 & -2.9 & 36154.5 & -11.2 \\
\hline 2017 & 43264.7 & 49607.2 & 9868 & 5326.5 & 18.9 & 39144 & 8.3 \\
\hline 2018 & 47335 & 57187.6 & 10714.3 & 5476.1 & 11.7 & 40020.9 & 2.2 \\
\hline
\end{tabular}

Source: Authors 
Germany, the Netherlands, Italy, Hungary, as well as China, Turkey and the Russian Federation. Deliveries for these countries, including Russia, accounted for more than half of Ukraine's total exports. The main partner countries in import are still the countries of the European Union, China and the Russian Federation.

To improve trade and economic cooperation with some particular countries or groups of countries, Ukraine uses a kind of instrument like free trade agreements covering over issues on the whole merchandise (industrial, agricultural, fish and marine products, etc.), services and dispute settlement, which is prominent and effective method for promoting export growth through the liberalization of goods and services access to foreign markets (Ministry for Development of Economy, Trade and Agriculture of Ukraine, 2020). Such agreements help to stimulate foreign trade, scientific, technical and trade-economic cooperation, promote innovation, investment, new technologies, and generally they increase the competitiveness of export-oriented industries. Let us examine empirically the way the important factors chosen affect Ukraine's foreign trade.

\section{Empirical results}

The investigations of statistical databases through the period of 1999 to 2018 were conducted. The results

Table 2

The Correlation Coefficients Matrix

\begin{tabular}{|c|c|c|c|c|c|}
\hline & FT & GDP & FDI & LM & SI \\
\hline FT & 1 & 0.2662 & 0.8395 & -0.2014 & 0.7103 \\
\hline GDP & 0.2662 & 1 & 0.1447 & 0.0520 & 0.2201 \\
\hline FDI & 0.8395 & 0.1447 & 1 & -0.5928 & 0.2950 \\
\hline LM & -0.2014 & 0.0520 & -0.5928 & 1 & 0.3588 \\
\hline SI & 0.7103 & 0.2201 & 0.2950 & 0.3588 & 1 \\
\hline
\end{tabular}

Source: Authors of the authors' study made it possible to explain the relationship between the selected variables using the E-Views software. Correlation matrix was constructed to explain the relationship between the selected variables (see Table 2).

The above correlation coefficient matrix shows strong correlation between foreign trade in goods and services and FDI of $84 \%$ with sufficiently strong correlation with expenses on innovation - 71\%, negative correlation between foreign trade and level employment. If there is negative correlation, decreasing value of one variable causes the other variable to increase. Acceptable result of correlation between variables confirms the success of this model. The results of multivariate regression are shown in the Table 3.

$\mathrm{R}^{2}$ shows the extent to which the selected variables and their level explain the extent of exports and imports of goods and services in Ukraine, i. e., selected variables with a high probability of $94.4 \%$ reflect the outlined links. Strong enough link shows correlation coefficient of $92.9 \%$; F-statistic $=0.000000$, the probability of accepting null hypothesis confirms the need to take an alternative hypothesis, which attests to the significance of equation in the whole.

According to Fisher's F-statistics, all coefficients of regression equation are not equal to 0 ( $\mathrm{p}$-value $<0.05$ ). In our equation, foreign direct investment and innovation costs are less than 5-10\%; the smaller the Prob., the better is the equation: $\mathrm{FDI}=0 \%, \mathrm{SI}=0.01 \%$.

We check the equation for autocorrelation using the Durbin-Watson test. This Durbin-Watson criterion is $\mathrm{d}=1.90$. From the Durbin-Watson statistics table, we determine significant points $d_{L}$ and $d_{U}$. For the number of observations of 20 to 4 variables when the level of significance is $\alpha=1 \% \mathrm{~d}_{\mathrm{L}}=0,68$ and $\mathrm{d}_{\mathrm{U}}=1,57$; and when $5 \%$ significance level $\mathrm{d}_{\mathrm{L}}=0,9$ and $\mathrm{d}_{\mathrm{U}}=1,83$. In our case, $\mathrm{DW}>\mathrm{d}_{\mathrm{U}}$, which means absence of autocorrelation.

Table 3

The Results of Multi-factor Regression of Foreign Trade

\begin{tabular}{|c|c|c|c|c|}
\hline \multicolumn{5}{|c|}{$\begin{array}{l}\text { Dependent Variable: FT Method: Least Squares } \\
\text { Sample: } 19992018 \text { Included observations: } 20\end{array}$} \\
\hline Variable & Coefficient & Std. Error & $\mathrm{t}$-Statistic & Prob. \\
\hline GDP & 0.025464 & 0.028886 & 0.881513 & 0.3919 \\
\hline FDI & 1.906067 & 0.266206 & 7.160129 & 0.0000 \\
\hline LM & 1997.054 & 2967.122 & 0.673061 & 0.5111 \\
\hline SI & 3661,292 & 717.3296 & 5.104058 & 0.0001 \\
\hline $\mathrm{C}$ & -27467.91 & 58209.35 & -0.471881 & 0.6438 \\
\hline
\end{tabular}

\begin{tabular}{|l|l|l|c|}
\hline R-squared & 0.944150 & Mean dependent var & 100377.0 \\
\hline Adjusted R-squared & 0.929256 & S.D. dependent var & 47440.08 \\
\hline S.E. of regression & 12617.96 & Akaike info criterion & 21.93595 \\
\hline Sum squared resid & $2.39 \mathrm{E}+09$ & Schwarz criterion & 22.18488 \\
\hline Log likelihood & -214.3595 & Hannan-Quinn criter. & 21.98454 \\
\hline F-statistic & 63.39378 & Durbin-Watson stat & 1.909408 \\
\hline Prob(F-statistic) & 0.000000 & & \\
\hline
\end{tabular}

Source: Authors 
We test the model for heteroskedasticity using the White, Breusch-Pagan-Godfrey, Harvey, Glejser, $\mathrm{ARCH}$ tests. The first White test is the most widely used in practice. Using the White test, regression of model residuals from variables is constructed. By the value of the probability of acceptance of the null hypothesis, we observe that almost all variables are not statistically significant, since the presence of the null hypothesis is more than $5 \%$. According to the presence of regression value in full $17 \%$, which is also higher than of $5 \%$ peg, respectively, we can accept the null hypothesis, and this confirms that in our model there is no heteroskedasticity (i.e., the residuals of the model have constant variance) (Table 4).

The Breusch-Pagan-Godfrey test checks the linear dependence of the variance of random errors upon some set of variables. The regression is not significant, the probability of accepting the null hypothesis is 0.2040 (20\%), which is more than 5\% and confirms the absence in the model of heteroskedasticity (Table 5).

The next heteroskedasticity test is the Harvey test, which is similar to the Breusch-Pagan-Godfrey test, and it is to check the hypothesis of the persistence of the variance of residues, and has an alternative hypothesis that the heteroskedasticity of type is observed (Table 6). In other words, exponential dependence is manifested here. The results of this test show that the probability of accepting null hypothesis is 0.3317 (33.1\%), which is more than $5 \%$ and confirms the absence of heteroskedasticity in the model.

The Glejser test evaluates the regression dependence of the deviation modules. The presence of regression significance on the level of F-statistic $=13.92 \%$ and $\mathrm{R}^{2}=13 \%$ is higher than the value of $10 \%$ peg, that is the model has no heteroskedasticity (Table 7 ). By varying $\mathrm{k}$ it is possible to construct different regression equations.

Another heteroskedasticity test is ARCH. The results of the test are shown in Table 8. The ARCH test also indicates that there is no heteroskedasticity in the model, the probability of accepting null hypothesis is $0.3152(31.5 \%)$, which is more than $5 \%$.

With the help of all the tests for heteroskedasticity checking, we affirm that null hypothesis can be accepted. In all tests for heteroskedasticity, the null hypothesis means absence of heteroskedasticity, but alternative presence. We accepted null hypothesis because the

Table 4

The Heteroskedasticity Test: White

\begin{tabular}{|c|c|c|c|}
\hline \multicolumn{1}{|c|}{ F-statistic } & Prob. F(14,5) & 0.1705 \\
\hline \multicolumn{1}{|c|}{ Obs*R-squared } & 17.40978 & Prob. Chi-Square(14) & 0.2350 \\
\hline \multicolumn{1}{|c|}{ Scaled explained SS } & 6.509242 & Prob. Chi-Square(14) & 0.9520 \\
\hline $\begin{array}{l}\text { Test Equation: Dependent Variable: RESID^2 } \\
\text { Method: Least Squares } \\
\text { Sample: } 1999 \text { 2018 Included observations: } 20\end{array}$ & \\
\hline
\end{tabular}

\begin{tabular}{|c|c|c|c|c|}
\hline Variable & Coefficient & Std. Error & t-Statistic & Prob. \\
\hline C & $4.41 \mathrm{E}+10$ & $1.79 \mathrm{E}+10$ & 2.455777 & 0.0575 \\
\hline GDP & 146092.4 & 55345.59 & 2.639639 & 0.0460 \\
\hline GDP^2 & 0.049553 & 0.027166 & 1.824091 & 0.1277 \\
\hline GDP*FDI & -0.355067 & 0.232084 & -1.529910 & 0.1866 \\
\hline GDP*LM & -9026.934 & 3329.963 & -2.710821 & 0.0422 \\
\hline GDP*SI & 1731.845 & 926.4326 & 1.869370 & 0.1205 \\
\hline FDI & -579009.4 & 215521.8 & -2.686546 & 0.0435 \\
\hline FDI^2 & 0.838512 & 0.754526 & 1.111309 & 0.0295 \\
\hline FDI $^{*}$ LM & 32562.57 & 10795.56 & 3.016293 & 0.1225 \\
\hline FDI*SI & -4148.114 & 2233.976 & -1.856831 & 0.0518 \\
\hline LM & $-4.49 \mathrm{E}+09$ & $1.76 \mathrm{E}+09$ & -2.542114 & 0.0465 \\
\hline LM $^{*} 2$ & $1.15 \mathrm{E}+08$ & 43614625 & 2.631054 & 0.4395 \\
\hline LM $^{*}$ SI & 15020699 & 17893209 & 0.839464 & 0.6924 \\
\hline SI & $-1.27 \mathrm{E}+08$ & $3.02 \mathrm{E}+08$ & -0.419243 & 0.1206 \\
\hline SI^2 & -8967791. & 4798838. & -1.868742 & \\
\hline
\end{tabular}

\begin{tabular}{|l|l|l|c|}
\hline R-squared & 0.870489 & Mean dependent var & $1.19 \mathrm{E}+08$ \\
\hline Adjusted R-squared & 0.507859 & S.D. dependent var & $1.41 \mathrm{E}+08$ \\
\hline S.E. of regression & 99093547 & Akaike info criterion & 39.77473 \\
\hline Sum squared resid & $4.91 \mathrm{E}+16$ & Schwarz criterion & 40.52153 \\
\hline Log likelihood & -382.7473 & Hannan-Quinn criter. & 39.92052 \\
\hline F-statistic & 2.400485 & Durbin-Watson stat & 2.799546 \\
\hline Prob(F-statistic) & 0.170488 & & \\
\hline
\end{tabular}

Source: Authors 
Vol. 6, No. 3, 2020

Table 5

Heteroskedasticity Test: Breusch-Pagan-Godfrey

\begin{tabular}{|l|l|l|l|}
\hline F-statistic & 1.692383 & Prob. F(4,15) & 0.2040 \\
\hline Obs*R-squared & 6.219271 & Prob. Chi-Square(4) & 0.1834 \\
\hline Scaled explained SS & 2.325287 & Prob. Chi-Square(4) & 0.6762 \\
\hline $\begin{array}{l}\text { Test Equation: Dependent Variable: RESID^2 } \\
\text { Method: Least Squares } \\
\text { Sample: } 1999 \text { 2018 Included observations: } 20\end{array}$ \\
\hline
\end{tabular}

\begin{tabular}{|c|c|c|c|c|}
\hline Variable & Coefficient & Std. Error & t-Statistic & 1.850533 \\
\hline C & $1.13 \mathrm{E}+09$ & $6.09 \mathrm{E}+08$ & -0.232045 & 0.0840 \\
\hline GDP & -70.10122 & 302.1019 & -0.220024 & 0.8196 \\
\hline FDI & -612.5624 & 2784.073 & -1.768163 & 0.8288 \\
\hline SI & -54868254 & 31031217 & 1.055219 & 0.0974 \\
\hline
\end{tabular}

\begin{tabular}{|l|l|l|c|}
\hline R-squared & 0.310964 & Mean dependent var & $1.19 \mathrm{E}+08$ \\
\hline Adjusted R-squared & 0.127220 & S.D. dependent var & $1.41 \mathrm{E}+08$ \\
\hline S.E. of regression & $1.32 \mathrm{E}+08$ & Akaike info criterion & 40.44626 \\
\hline Sum squared resid & $2.61 \mathrm{E}+17$ & Schwarz criterion & 40.69519 \\
\hline Log likelihood & -399.4626 & Hannan-Quinn criter. & 40.49486 \\
\hline F-statistic & 1.692383 & Durbin-Watson stat & 2.122781 \\
\hline Prob(F-statistic) & 0.203963 & & \\
\hline
\end{tabular}

Source: Authors

Table 6

Heteroskedasticity Test: Harvey

\begin{tabular}{|c|c|c|c|}
\hline F-statistic & 1.251663 & Prob. $F(4,15)$ & 0.3317 \\
\hline Obs ${ }^{*} \mathrm{R}$-squared & 5.004987 & Prob. Chi-Square(4) & 0.2868 \\
\hline Scaled explained SS & 3.805318 & Prob. Chi-Square(4) & 0.4330 \\
\hline $\begin{array}{l}\text { Test Equation: Deper } \\
\text { Method: Least Squar } \\
\text { Sample: } 19992018 \mathrm{I}\end{array}$ & & & \\
\hline
\end{tabular}

\begin{tabular}{|c|c|c|c|c|}
\hline Variable & Coefficient & Std. Error & $\mathrm{t}$-Statistic & Prob. \\
\hline $\mathrm{C}$ & 31.48558 & 8.934291 & 3.524127 & 0.0031 \\
\hline GDP & $1.30 \mathrm{E}-06$ & $4.43 \mathrm{E}-06$ & 0.292969 & 0.7736 \\
\hline FDI & $-1.80 \mathrm{E}-05$ & $4.09 \mathrm{E}-05$ & -0.440702 & 0.6657 \\
\hline LM & -0.768098 & 0.455410 & -1.686606 & 0.1124 \\
\hline SI & 0.106464 & 0.110100 & 0.966980 & 0.3489 \\
\hline
\end{tabular}

\begin{tabular}{|l|l|l|c|}
\hline R-squared & 0.250249 & Mean dependent var & 17.39416 \\
\hline Adjusted R-squared & 0.050316 & S.D. dependent var & 1.987317 \\
\hline S.E. of regression & 1.936675 & Akaike info criterion & 4.372140 \\
\hline Sum squared resid & 56.26063 & Schwarz criterion & 4.621073 \\
\hline Log likelihood & -38.72140 & Hannan-Quinn criter. & 4.420734 \\
\hline F-statistic & 1.251663 & Durbin-Watson stat & 2.155326 \\
\hline Prob(F-statistic) & 0.331739 & & \\
\hline
\end{tabular}

Source: Authors

probability of accepting the hypothesis is much above $5 \%$ significance level.

We also test the model for predictive quality. We pay attention to MAPE, which is equal to 9.35 , i. e., being high accuracy of the forecast, and therefore high quality of the forecast (Figure 1).

We test the model for explanatory ability. Figure 2 shows how the model we built clearly reflects foreign trade by the factors we choose: a graph where the modeled values
(Fitted) accurately represent actual values (Actual), so by this criterion the model is completely acceptable.

We used the Granger test to investigate the causeand-effect relationships between the selected variables and the FT. The idea of test is as follows: if a change in variable $\mathrm{X} 1$ causes a change in $\mathrm{X} 2$, then change $\mathrm{X} 1$ precedes change $\mathrm{X} 2$; that is, we check whether $\mathrm{X} 1$ or $\mathrm{X} 2$ has been primal. The tests were performed for lags 2, 3, 4. The test results are shown in Table 9. 
Table 7

\section{Heteroskedasticity Test: Glejser}

\begin{tabular}{|l|l|l|l|}
\hline F-statistic & \multicolumn{1}{|c|}{2.046543} & Prob. F(4,15) & 0.1392 \\
\hline Obs*R-squared & 7.061254 & Prob. Chi-Square(4) & 0.1327 \\
\hline Scaled explained SS & 5.186355 & Prob. Chi-Square(4) & 0.2687 \\
\hline $\begin{array}{l}\text { Test Equation: Dependent Variable: ARESID } \\
\text { Method: Least Squares } \\
\text { Sample: } 1999 \text { 2018 Included observations: } 20\end{array}$ & \\
\hline
\end{tabular}

\begin{tabular}{|c|c|c|c|c|}
\hline Variable & Coefficient & Std. Error & t-Statistic & Prob. \\
\hline C & 62466.58 & 27929.56 & 2.236576 & 0.0409 \\
\hline GDP & -0.000665 & 0.013860 & -0.048007 & 0.9623 \\
\hline FDI & -0.054478 & 0.127729 & -0.426511 & 0.6758 \\
\hline LM & -2939.249 & 1423.662 & -2.064570 & 0.0567 \\
\hline SI & 468.4373 & 344.1835 & 1.361010 & 0.1936 \\
\hline
\end{tabular}

\begin{tabular}{|l|l|l|l|}
\hline R-squared & 0.353063 & Mean dependent var & 8770.205 \\
\hline Adjusted R-squared & 0.180546 & S.D. dependent var & 6688.032 \\
\hline S.E. of regression & 6054.254 & Akaike info criterion & 20.46723 \\
\hline Sum squared resid & $5.50 \mathrm{E}+08$ & Schwarz criterion & 20.71616 \\
\hline Log likelihood & -199.6723 & Hannan-Quinn criter. & 20.51582 \\
\hline F-statistic & 2.046543 & Durbin-Watson stat & 2.100809 \\
\hline Prob(F-statistic) & 0.139161 & & \\
\hline
\end{tabular}

Source: Authors

Table 8

\section{Heteroskedasticity Test: ARCH}

\begin{tabular}{|l|l|l|c|}
\hline F-statistic & \multicolumn{1}{|c|}{1.071150} & Prob. F(1,17) & 0.3152 \\
\hline Obs*R-squared 1.126207 & Prob. Chi-Square(1) & 0.2886 \\
\hline Test Equation: Dependent Variable: RESID^2 & \\
Method: Least Squares Sample (adjusted): 2000 2018 \\
Included observations: 19 after adjustments
\end{tabular}

\begin{tabular}{|c|c|c|c|c|}
\hline Variable & Coefficient & Std. Error & t-Statistic & Prob. \\
\hline C & 97105137 & 42443928 & 2.287845 & 0.0352 \\
\hline RESID $2(-1)$ & 0.264514 & 0.255578 & 1.034964 & 0.3152 \\
\hline
\end{tabular}

\begin{tabular}{|l|l|l|c|}
\hline R-squared & 0.059274 & Mean dependent var & $1.25 \mathrm{E}+08$ \\
\hline Adjusted R-squared & 0.003937 & S.D. dependent var & $1.43 \mathrm{E}+08$ \\
\hline S.E. of regression & $1.42 \mathrm{E}+08$ & Akaike info criterion & 40.48598 \\
\hline Sum squared resid & $3.45 \mathrm{E}+17$ & Schwarz criterion & 40.58540 \\
\hline Log likelihood & -382.6168 & Hannan-Quinn criter. & 40.50281 \\
\hline F-statistic & 1.071150 & Durbin-Watson stat & 1.948456 \\
\hline Prob(F-statistic) & 0.315185 & & \\
\hline
\end{tabular}

Source: Authors

The Granger test results can be summarized. If lag $=2$, so foreign trade reveals a cause-and-effect dependence on the employed citizens, namely, foreign trade is the reason for the increase in the number of employed population: the higher the volume of exports and imports (especially intermediate consumption products, which need further processing) is, the greater the need for the labor force is, and thus the higher the employment rate in the countries is. Also, the more foreign investment is attracted, which usually contributes to production and GDP growth, the more people are going to be employed, so the employment rate will increase. The descriptive characteristics of the variables are shown in Table 10.
External trade, GDP and FDI, have the highest standard deviation, which confirms their general tendency for volatility and means that both external and internal factors influence these variables. The external environment directly influences Ukraine's foreign trade and its economic development in general. Manufacturing, exporting and importing, attracting investment in our model demonstrate close connection with the employed population.

The skewness coefficients are insignificant in terms of foreign trade and FDI. Let us analyze the kurtosis index, which shows the amplitude of the deviations of the variables. If the kurtosis rate is 


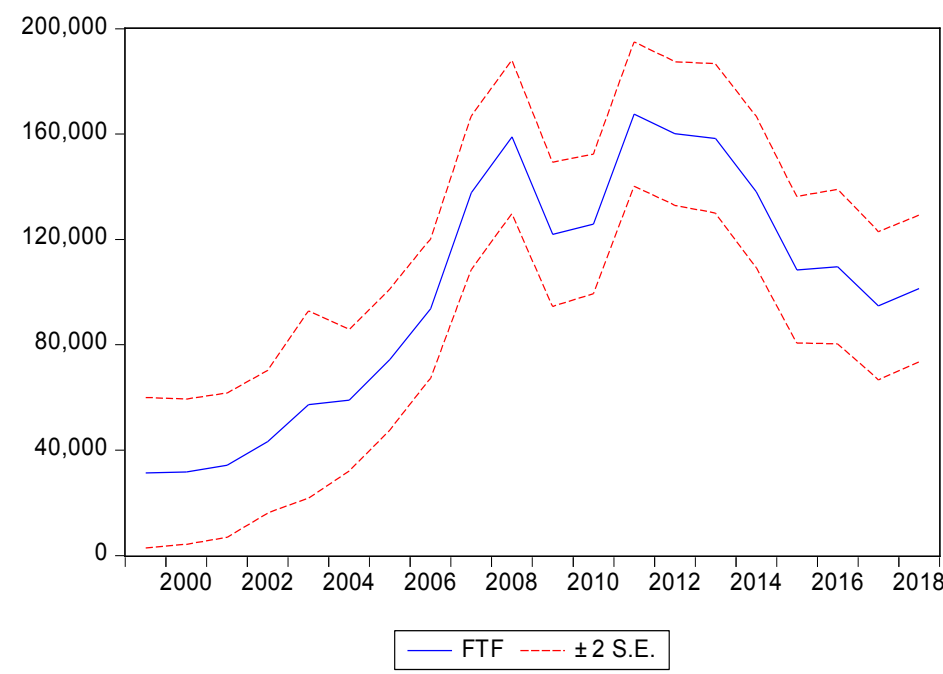

Forecast: FTF

Actual: FT

Forecast sample: 19992018

Included observations: 20

Root Mean Squared Error

Mean Absolute Error

10927.48

Mean Abs. Percent Error

8770.205

Theil Inequality Coefficient 0.049560

Bias Proportion $\quad 0.000000$

Variance Proportion $\quad 0.014367$

Covariance Proportion $\quad 0.985633$

Figure 1. Forecast of models

Source: Authors

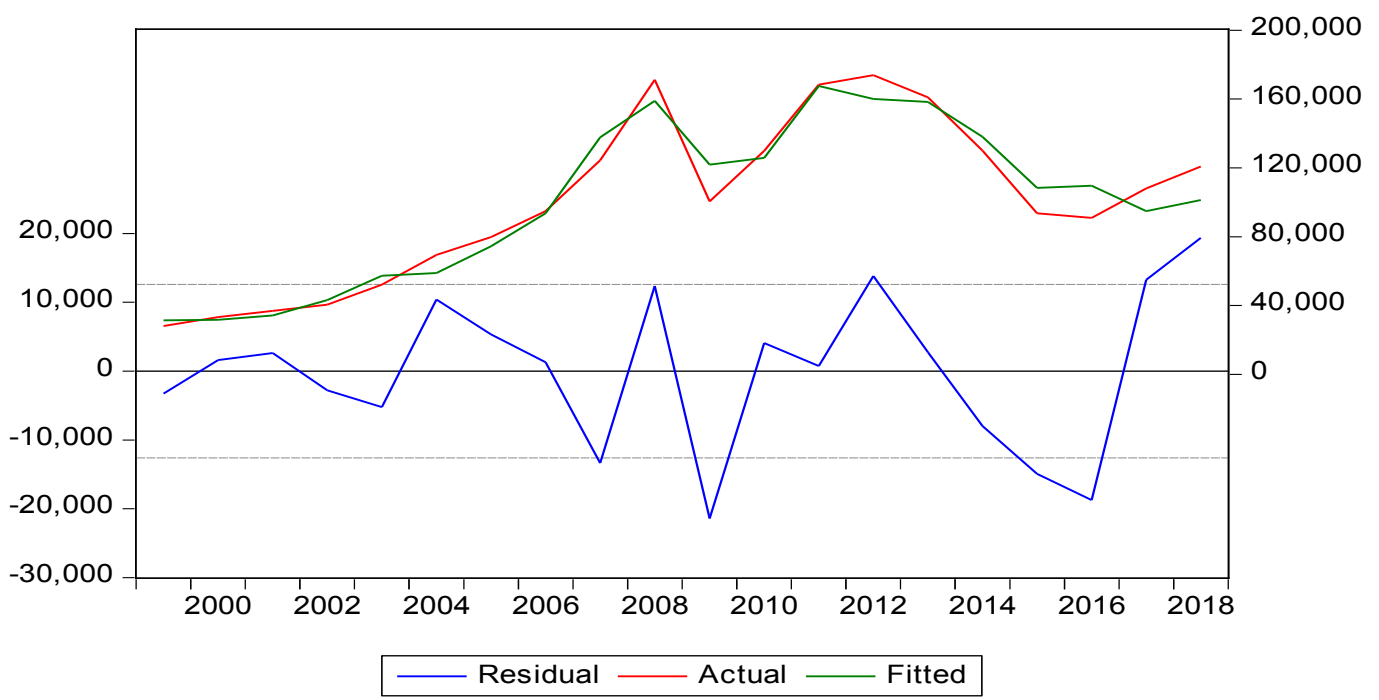

Figure 2. Explanatory ability of the model

Source: Authors

greater than 0 , then the sharp-pointed distribution and the amplitude are considered to be significant, but if the kurtosis factor is less than 0 , then the distribution is considered to be planar (flat-topped) and the amplitude is considered insignificant. In our model, all indices of kurtosis are greater than 0 , so the distribution is acute-vertex. The null hypothesis of all variables except GDP has normal distribution on the level of $5 \%$. The standard deviation indicates on small coefficient of variation. The results of the Dickey-Fuller stationarity test showed that all the data were stationary (stable).

Taking into account all the indicators of high quality, according to actual data, we make a forecast of foreign trade up to 2023 (Figure 3). With the dynamics of the selected factors, we predict the probability of exports and imports growth for goods and services at certain intervals.

The equation is statistically significant with a high coefficient of determination. The general view of the model on the dependence of foreign trade upon independent variables can be described by the following equation:

Substituted Coefficients:

$\mathrm{FT}=0.0254 \mathrm{x}$ GDP $+1.9060 \mathrm{x}$ FDI $+1997.0540 \mathrm{x}$

$x \mathrm{LM}+3661.2918 \mathrm{x}$ SI -27467.9050

At the same time, considering the newest aspects of the pandemic course of the coronavirus and the response of countries and the world economy in the whole, predicting on high probability, we consider achieving Ukraine's foreign trade parameters in accordance with the pessimistic forecasting scenario. 
Table 9

Pairwise Granger Causality test on all the variables, 1999-2018

\begin{tabular}{|c|l|c|c|c|c|c|c|c|}
\hline \multirow{2}{*}{ Null hypothesis } & \multicolumn{3}{|c|}{ lag 2} & \multicolumn{2}{c|}{ lag 3 } & \multicolumn{2}{c|}{ lag 4} \\
\cline { 3 - 8 } & & F-Statistic & Prob. & Conclusion & F-Statistic & Prob. & F-Statistic & Prob. \\
\hline 1 & GDP does not Granger Cause FT & 0.01291 & 0.9872 & accept & 0.02041 & 0.9958 & 0.11204 & 0.9743 \\
\hline & FT does not Granger Cause GDP & 0.14939 & 0.8627 & accept & 0.12958 & 0.9403 & 0.66341 & 0.6370 \\
\hline 2 & FDI does not Granger Cause FT & 0.32717 & 0.7267 & accept & 0.45132 & 0.7220 & 0.44222 & 0.7754 \\
\hline & FT does not Granger Cause FDI & 2.62583 & 0.1102 & accept & 1.98435 & 0.1803 & 0.82629 & 0.5483 \\
\hline 3 & LM does not Granger Cause FT & 0.03434 & 0.9663 & accept & 0.18901 & 0.9015 & 0.19686 & 0.9323 \\
\hline & FT does not Granger Cause LM & 6.49481 & 0.0111 & reject & 3.13873 & 0.0740 & 3.11128 & 0.0907 \\
\hline 4 & SI does not Granger Cause FT & 0.34038 & 0.7177 & accept & 0.97783 & 0.4414 & 0.67693 & 0.6292 \\
\hline & FT does not Granger Cause SI & 0.15701 & 0.8563 & accept & 0.91816 & 0.4668 & 0.44691 & 0.7723 \\
\hline 5 & FDI does not Granger Cause GDP & 0.22118 & 0.8045 & accept & 0.25065 & 0.8591 & 0.97391 & 0.4785 \\
\hline & GDP does not Granger Cause FDI & 0.04224 & 0.9588 & accept & 0.31484 & 0.8144 & 0.19337 & 0.9342 \\
\hline 6 & LM does not Granger Cause GDP & 0.72114 & 0.5047 & accept & 0.38752 & 0.7645 & 1.96462 & 0.2046 \\
\hline & GDP does not Granger Cause LM & 0.23584 & 0.7932 & accept & 0.09995 & 0.9582 & 0.03817 & 0.9965 \\
\hline 7 & SI does not Granger Cause GDP & 0.27676 & 0.7626 & accept & 0.10781 & 0.9536 & 0.07468 & 0.9877 \\
\hline & GDP does not Granger Cause SI & 0.02660 & 0.9738 & accept & 0.00687 & 0.9992 & 0.65658 & 0.6410 \\
\hline 8 & LM does not Granger Cause FDI & 1.95134 & 0.1815 & accept & 2.09072 & 0.1651 & 1.66109 & 0.2616 \\
\hline & FDI does not Granger Cause LM & 3.97883 & 0.0449 & reject & 6.04163 & 0.0129 & 4.32586 & 0.0448 \\
\hline 9 & SI does not Granger Cause FDI & 3.23497 & 0.0724 & accept & 2.92802 & 0.0862 & 1.70795 & 0.2516 \\
\hline & FDI does not Granger Cause SI & 0.38398 & 0.6886 & accept & 1.94271 & 0.1867 & 1.42455 & 0.3197 \\
\hline 10 & SI does not Granger Cause LM & 3.71458 & 0.0530 & accept & 1.24627 & 0.3442 & 1.36608 & 0.3364 \\
\hline & LM does not Granger Cause SI & 1.15774 & 0.3446 & accept & 1.64475 & 0.2410 & 0.73026 & 0.5991 \\
\hline
\end{tabular}

Source: Authors

Table 10

Characteristics of variables

\begin{tabular}{|l|c|c|c|c|c|}
\hline & FT & GDP & FDI & LM & SI \\
\hline Mean & 100377.0 & 132006.1 & 26680.71 & 19.27385 & 9.597000 \\
\hline Median & 97686.95 & 117591.5 & 32633.05 & 20.03135 & 8.805000 \\
\hline Maximum & 173942.5 & 513315.0 & 53704.00 & 21.00370 & 22.77000 \\
\hline Minimum & 28154.80 & 31580.90 & 2810.700 & 16.15640 & 2.940000 \\
\hline Std. Dev. & 47440.08 & 103301.3 & 18403.89 & 1.684786 & 5.889824 \\
\hline Skewness & 0.032692 & 2.548740 & -0.091876 & -0.924753 & 0.888673 \\
\hline Kurtosis & 1.909492 & 10.47516 & 1.445950 & 2.406134 & 2.897351 \\
\hline & & & & & 3.144456 \\
\hline Jarque-Bera & 0.994569 & 68.21865 & 2.040696 & 0.207582 & 2.641249 \\
\hline Probability & 0.608180 & 0.000000 & 0.360470 & & 0.266969 \\
\hline & & & & 385.4769 & 191.9400 \\
\hline Sum & 2007539. & 2640122. & 533614.1 & 53.93157 & 659.1104 \\
\hline Sum Sq. Dev. & $4.28 \mathrm{E}+10$ & $2.03 \mathrm{E}+11$ & $6.44 \mathrm{E}+09$ & & 20 \\
\hline
\end{tabular}

Source: Authors

\section{Implications}

The conducted investigation and literature review proved the relevance of the foreign trade effect research direction through the action of determinants of exogenous and endogenous origin. Justifying the priority of institutional changes as a prerequisite for further support of foreign trade, it should be pointed out that at present day on the level of the State the implementation of the Export Strategy of Ukraine ("Road Map" of Strategic Trade Development) for 2017-2021 is aimed at geospatial diversification of exports and import, the increase of high-tech innovative products export by the criteria of sustainable development, seeking for new sales markets as well (Ukraine's export strategy, 2020).

The results of the obtained econometric model allow us to determine the necessary focus of public policy onto the basis of selective approach, taking into account the variability of foreign investment factors, employment level, economic activity in the country in the whole and innovative activity of business engaged into foreign economic operations. 


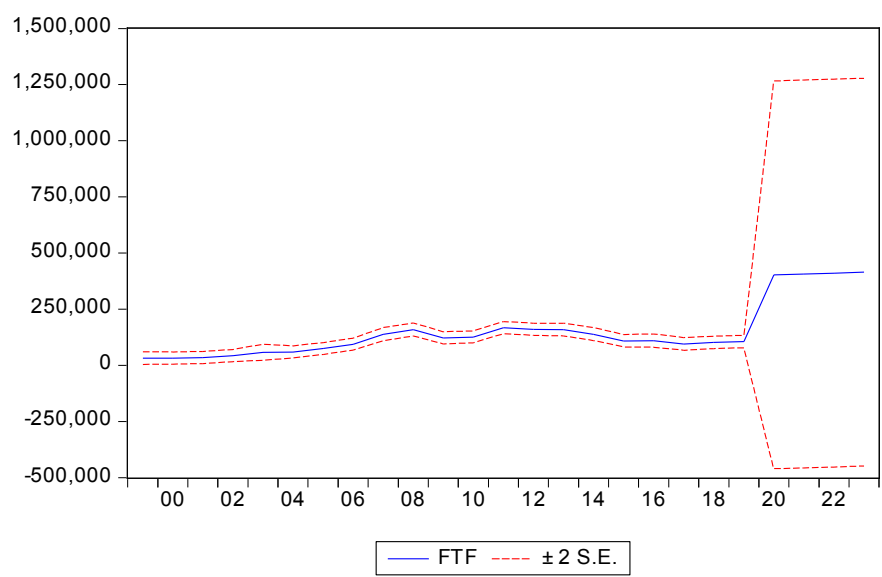

Forecast: FTF

Actual: FT

Forecast sample: 19992023

Included observations: 20

Root Mean Squared Error 10927.48

Mean Absolute Error $\quad 8770.205$

Mean Abs. Percent Error 9.354834

Theil Inequality Coefficient 0.049560

Bias Proportion $\quad 0.000000$

Variance Proportion $\quad 0.014367$

Covariance Proportion $\quad 0.985633$

Figure 3. Forecast: FTF

Source: Authors

The model showed higher level of trade sensitivity upon the level of employment and modernization of the industrial sector, which underpin innovation. The level of employment and its distribution across sectors of the economy are important, first of all, as for the sectoral specific nature of labor resource demand. Considering the fact that the level of automation and technical supply within the first five commodity groups for export is rather low, so the fluctuation of employment level in the outlined sectors is to imply significant affect upon the export opportunities of Ukraine all in all. In this context, large-scale labor migration from Ukraine during last ten years is clearly a destructive factor. The emphasis on stimulating innovation in industry and other sectors of the economy is also justified, since this ensures diversification of exports and enhances the competitiveness of companies, in particular small and medium-sized ones, integrated into international trade.

Proposals to complicate the structure of foreign trade and increase its level of adaptability and innovation are fully justified and urgent: as for 2019, the export structure in Ukraine remains of raw nature. Almost 70\% of exports are from agricultural products, metallurgical and chemical industries, mineral products, wood, and raw materials for light industry (Ukraine's export strategy, 2018). The situation is complicated by the fact that the dominance of the raw material component makes Ukraine's economy vulnerable from the worldwide unstable market conditions of agricultural, metal, chemical raw materials and energy engineering. These sectors are the first to respond to the recessionary processes in the world economy. The Coronavirus outbreak in 2020 is a major challenge for both global and foreign trade in Ukraine, where export markets (the EU, the PRC) have been impacted badly by the pandemic. Additional destructive influence is exerted state of relations between Ukraine and the Russian Federation. Trade relations of Ukraine with the Russian Federation have declined substantially, restrictive measures on export deliveries are in force through some other CIS and Asian countries.

Increasing technological level of exports, some experts quite truly connect the involvement of small and medium-sized businesses into international production networks of multinational companies (Duginets G., Koval V., Plekhanova O., Antonov A., Petrova M., 2019). However, it should be borne in mind that, as a rule, such cooperation is being in the format of contractual rather than investment relations, and the localization is carried out by low-tech processes and operations. Accordingly, there is no significant shift towards modernizing industrial sector and increasing level of tech-adaptability of the economy and the external sector.

\section{Conclusions}

Resulting on the modelling simulation it has been found, that:

- high level achievement in foreign trade dynamics of Ukraine over the years, which exceeded similar indicators of dynamics within global trade;

- existing strong link between foreign trade, foreign direct investment and employment rates, and which is less dense - in terms of overall economic activity of the country that is manifested through GDP;

- higher levels of trade sensitivity than employment and modernization of the industrial sector. Employment fluctuations across sectors that provide priority export groups (agro-industrial complex, metallurgy, machinebuilding) which may seriously affect entire Ukraine's export potential;

- strengthening of institutional support for innovation and investment activities of national enterprises that should be considered within the potential of scale-up and improvement of Ukraine's trade relations quality with the whole world;

- animated interaction of innovations and investments is to provide diversification and complication of 
merchandise export structure, to increase its level of tech-adaptability and innovativeness, and thus allow to get rid of the established attitude to Ukraine on the world trade map as to a supplier of raw low-tech products.

Prospects for further research in this area may be the estimation of risks and macroeconomic effects of foreign trade deterioration in the context of declining economic activity in the importing countries of domestic products, especially in the EU and the PRC, further weakening the external channels of investment and reducing the ability of businesses to innovate in deepening recessionary processes on global and national levels.

Through the timing period of the represented study, the S\&P international agency downgraded the global rating of indicators, including Ukraine, as well. In particular, Ukraine's real GDP growth is projected to decline down to the level of $2.5 \%$ to $3.0 \%$ in 2020 , and it is to stabilize on the 3\% level in 2022-2023 (Rating: Ukraine; Telegraf, 2020). All in all, the forecasts based on the developed foreign trade model do not contradict the forecasts of the S\&P international agency: Ukraine's foreign trade is to increase; however, the effects of foreign trade will be determined not just by institutional, but rather through factorial endogenous and exogenous preconditions.

\section{Acknowledgements}

The article is prepared within the framework of the Scientific research work "The potential of import substitution in Ukraine on conditions of post-industrial economy formation" (state registration number 0119U100625).

\section{References:}

Constantinescu, Cristina, Aaditya Mattoo and Michele Ruta (2014). Global Trade Slowdown: Cyclical or Structural? IMF Working Paper, January 2015. Retrieved 15 March, 2020 from: https://www.imf.org/external/ pubs/ft/wp/2015/wp1506.pdf

Economic trends / Trade Trends / Exports and imports of total services, goods, value, shares, and growth, annual (2018). Retrieved 10 March, 2020 from: https://unctadstat.unctad.org/wds/ReportFolders

Economic statistics / International economic activity and balance of payments (2020) Retrieved 05 March, 2020 from: http://www.ukrstat.gov.ua/

Sook-Yen, Lee and Chin Mui-Yin (2018). Revising the Impact of Trade Openness on Economic Growth International Academic Journal of Accounting and Financial Management Volume 5, Issue 2, 2018. Retrieved 12 March, 2020 from: https://www.iaiest.com/data-cms/articles/20191104093529amIAJAFM1810025.pdf

Razin A., Sadka E., \& Coury T. (2003). Trade Openness, Investment Instability and Terms-of-Trade Volatility. Journal of International Economics, vol. 61(2), pp. 285-306. doi: 10.1016/S0022-1996(03)00014-X

Ceyhun Akarsu (2018). Globalization's effect on United States'. Terms of Trade Retrieved 09 March, 2020 from: https://www.academia.edu/38586778/Globalization_s_effect_on_United_States_Terms_of_Trade?auto=download Eglantina, H., \& Oltiana, N. (2016). Trade effect on economic growth of Balkan countries Retrieved 12 March, 2020 from: https://www.researchgate.net/publication/308112157_TRADE_EFFECT_ON_ECONOMIC_ GROWTH_OF_BALKAN_COUNTRIES

Engjëll Pere and Eniel Ninka (2017). International Trade in Western Balkan Countries: Analysis Based on the Gravity Model The wiiw Balkan Observatory. Working Papers November, 2017 Retrieved 12 March, 2020 from: https://wiiw.ac.at/international-trade-in-western-balkan-countries-analysis-based-on-the-gravity-modeldlp-4632.pdf

Chuhaiev, O. A. (2016). Efekty velychyny ekonomiky dlia mizhnarodnoi torhivli [The effects of the size of the economy on international trade]. Mizhnarodni vidnosyny, seriia ekonomichni nauky, no. 7. Retrieved 12 March, 2020 from: http://journals.iir.kiev.ua/index.php/ec_n/article/view/2919/2615

Nwosa P. I., Saibu M. O., \& Fakunle O. O. (2012). The Effect of Trade Liberalization On Trade Tax Revenue in Nigeria. African Economic and Business Review, vol. 10, no. 2. Retrieved 10 March, 2020 from: https://www.researchgate.net/profile/Olufemi_Saibu/publication/249992061 The Effect_of_Trade Liberalization On Trade Tax Revenue in Nigeria/links/0deec51e86aaa5340a0000000/The-Effect-of-TradeLiberalization-On-Trade-Tax-Revenue-in-Nigeria.pdf

Ejike, D., Arinze, A. S., \& Chidi, O. F. (2018). Trade liberalization and economic growth in Nigeria: a cointegration analysis (1980-2015). IJRDO - Journal of Business Management, vol. 4, no. 5 (2018), p. 81-94. Retrieved 12 March, 2020 from: https://www.ijrdo.org/index.php/bm/article/view/2076

Agbeyegbe, T., Stotsk, J. G. \& Wolde Mariam, A. (2004). Trade Liberalization, Exchange Rate Changes and Tax Revenue in Sub-Saharan Africa. IMF Working Paper WP/04/178. doi: 10.5089/9781451858983.001

Alessia Campolmi, Harald Fadinger, \& Chiara Forlati (2014). Trade Policy: Home Market Effect versus Terms-of-Trade Externality. Journal of International Economics, Elsevier, vol. 93(1), p. 92-107. doi: 10.1016/ j.jinteco.2013.12.010

Yanikkaya, Halit (2003). Trade openness and economic growth: A cross-country empirical investigation. Journal of Development Economics, 72: 57-89. doi: 10.1016/S0304-3878(03)00068-3

Evaluating the Trade Effect of Developing Regional Trade Agreements: A Semi-parametric Approach. World Bank Policy Research Working Paper, May, 2007. doi: 10.1596/1813-9450-4220 
Mahadeva, R. (2007). New Evidence on the Export-led Growth Nexus: A Case Study of Malaysia. World Economy, 30(7), p. 1069-1083, July. doi: 10.1111/j.1467-9701.2007.01030.x

Marilyne Huchet, Chantal Le Mouel, Mariana Vijil (2018). The relationship between trade openness and economy growth: Some new insights on the openness measurement issue. The World Economy, Wiley, 2018, 41(1), pp. 59-76. Retrieved 15 March, 2020 from: https://hal.archives-ouvertes.fr/hal-01987393/document

Economic trends / National accounts/ Gross domestic product: Total and per capita, current and constant (2010) prices, annual. Retrieved 10 March, 2020 from: https://unctadstat.unctad.org/wds/TableViewer/tableView.aspx Ministry for Development of Economy / Trade and Agriculture of Ukraine (2020). Free Trade Agreements. Retrieved 10 March, 2020 from: https://www.me.gov.ua/Documents/Detail?lang=uk-UA\&id=9538dee1-a00d4b82-8a8d-ccfaee253185\&title=UgodiProVilnuTorgivliu

Duginets, G., Koval, V., Plekhanova, O., Antonov, A., \&Petrova, M. (2019). On the supranational and national level of global value chain management. Entrepreneurship and Sustainability issues, vol. 6, no. 4 (June), pp. 1922-1937. doi: 10.9770/jesi.2019.6.4(27)

Rating: Ukraine Credit Rating (2020). Retrieved 06 March, 2020 from: https://countryeconomy.com/ratings/ ukraine

Reitynhovoe ahenstvo prohnozyruet zamedlenye ekonomyky Ukrainy (2020). Retrieved 12 March, 2020 from: https://telegraf.com.ua/biznes/ekonomika/5394490-reytingovoe-agenstvo-prognoziruet-zamedlenie-ekonomiki-ukrainyi.html 